\title{
Loss of Membranous Expression of $\beta$-Catenin Is Associated with Tumor Progression in Cutaneous Melanoma and Rarely Caused by Exon 3 Mutations
}

Anouk Demunter, Louis Libbrecht, Hugo Degreef, Chris De Wolf-Peeters, Joost J. van den Oord

Department of Pathology, Laboratory of Morphology and Molecular Pathology (AD, LL, CDW-P, JJvdO)

and Department of Dermatology (HD), University Hospitals, Katholieke Universiteit Leuven,

Leuven, Belgium

$\beta$-Catenin plays a fundamental role in the regulation of the E-cadherin-catenin cell adhesion complex. It also plays a role in the Wnt signaling pathway by activating T-cell factor- and lymphoid enhancer factor-regulated gene transcription. The level of $\beta$-catenin in cells is tightly controlled in a multiprotein complex, and mutations in the glyco-

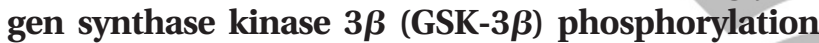
sites of the $\beta$-catenin gene (CTNNB1) result in nuclear and/or cytoplasmic accumulation of $\beta$-catenin and constitutive transactivation of $T$-cell factor and lymphoid enhancer factor target genes, a mechanism occurring in many cancers. Melanoma cell lines may harbor $\beta$-catenin mutations; in vivo, however, cellular accumulation of $\beta$-catenin is rarely caused by CTNNB1 mutations. In our study, 43 primary cutaneous melanoma and 30 metastases were screened for CTNNB1 exon 3 mutations by using a denaturing gradient gel electrophoresis technique and sequencing. $\beta$-Catenin mutations were found in 2 primary melanomas and 1 metastatic melanoma and were not correlated with nuclear accumulation of $\beta$-catenin in these cases. Cellular expression of $\beta$-catenin was evaluated by immunohistochemistry and by reverse polymerase chain reaction (RT-PCR) in 80 and 70 cases, respectively. Immunohistochemistry revealed a significant loss of membranous $\beta$-catenin staining between the primary and metastatic melanomas as well as between radial and vertical growth phase. RT-PCR showed a significant inverse correlation between the amount

Copyright () 2002 by The United States and Canadian Academy of Pathology, Inc.

VOL. 15, NO. 4, P. 454, 2002 Printed in the U.S.A.

Date of acceptance: December 12, 2001

This study was financially supported by Grant OT/98/33 of the Katholieke Universiteit Leuven (to AD), and by a grant from the Belgian Cancer Association (to CdW-P).

Address reprint requests to: A. Demunter, M.D., Dept. Pathology, Laboratory of Morphology and Molecular Pathology, University Hospital St. Rafael, Minderbroederstraat 12, B-3000 Leuven, Belgium; e-mail: anouk.demunter@uz.kuleuven.ac.be; fax: 00-32-16-33-65-48. of RNA and the proportion of cells with membranous expression of $\beta$-catenin $(P=.0015)$; no correlation existed between the amount of RNA and the number of cells with nuclear or cytoplasmic expression of $\beta$-catenin. In conclusion, nuclear expression of $\beta$-catenin is seen in cutaneous melanoma but, in contrast to the case of many other cancers, does not correlate with tumor stage or mutation status. A combination of immunohistochemistry and RTPCR showed that down-regulation of membranous $\beta$-catenin was associated with an increased amount of $\beta$-catenin RNA in primary or metastatic melanoma. Our results suggest that posttranslational events, rather than CTNNB1 mutations, are responsible for the altered distribution of $\beta$-catenin in cutaneous melanoma.

KEY WORDS: $\beta$-Catenin, DGGE, Immunohistochemistry, Melanoma, RT-PCR, Tumorigenesis.

Mod Pathol 2002;15(4):454-461

Cell-cell interactions play a key role in morphogenesis and maintenance of cellular differentiation; important regulators of these processes are the cadherins and catenins, which are involved in both cell-cell adhesion and signal transduction. Cadherins are transmembrane glycoproteins that mediate homotypic, $\mathrm{Ca}^{++}$-dependent cell-cell adhesion. Based on structural features, three subtypes of cadherins can be distinguished. E-cadherin is the major cadherin in epithelial cells, whereas $N$ cadherin is expressed mainly by mesenchymal cells. Melanocytes interact with epidermal keratinocytes via E- and P-cadherin $(1,2)$. The cytoplasmic domain of cadherins associates with a group of proteins, termed catenins ( $\alpha-, \beta$ - and $\gamma$-catenin), that connect the cadherins to the cytoskeleton (3). Besides its involvement in cell-cell adhesion, $\beta$-catenin also functions as a downstream molecule in the Wnt/wingless signaling pathway, where it forms complexes with the T-cell factor (Tcf) family 
of transcription factors (4). This complex formation enables $\beta$-catenin to enter the nucleus and to regulate gene transcription. In particular, cyclin D1 and c- $M y c$ have been reported to act as downstream targets of $\beta$-catenin and stimulate cell proliferation. In the absence of Wnt signals, the cellular concentration of $\beta$-catenin is kept relatively low through interactions with other proteins, such as adenomatous polyposis coli (APC) protein (5), GSK3 $\beta$ (6) and axin (7), that are involved in the phosphorylation of $\beta$-catenin. This phosphorylated form of $\beta$-catenin is degraded by the ubiquitinproteasome system (8; Fig. 1). Exon 3 of the $\beta$-catenin gene (CTNNB1), which represents the putative GSK3 $\beta$-mediated phosphorylation site, is a very important region because mutations in these sites disrupt the phosphorylation of the protein and result in stabilization of $\beta$-catenin. The accumulating $\beta$-catenin may subsequently translocate into the nucleus, where it acts as an oncoprotein through constitutive Tcf-regulated transcription of target genes that activate cell proliferation $(9,10)$. This mechanism is thought to play an important role in oncogenesis and tumor progression. In line with this, reduction or even loss of membranous $\beta$-catenin expression and accumulation of the protein in the cytoplasm and/or nucleus has been found in a number of malignant tumors (11). In certain neoplasms, this altered expression corre-

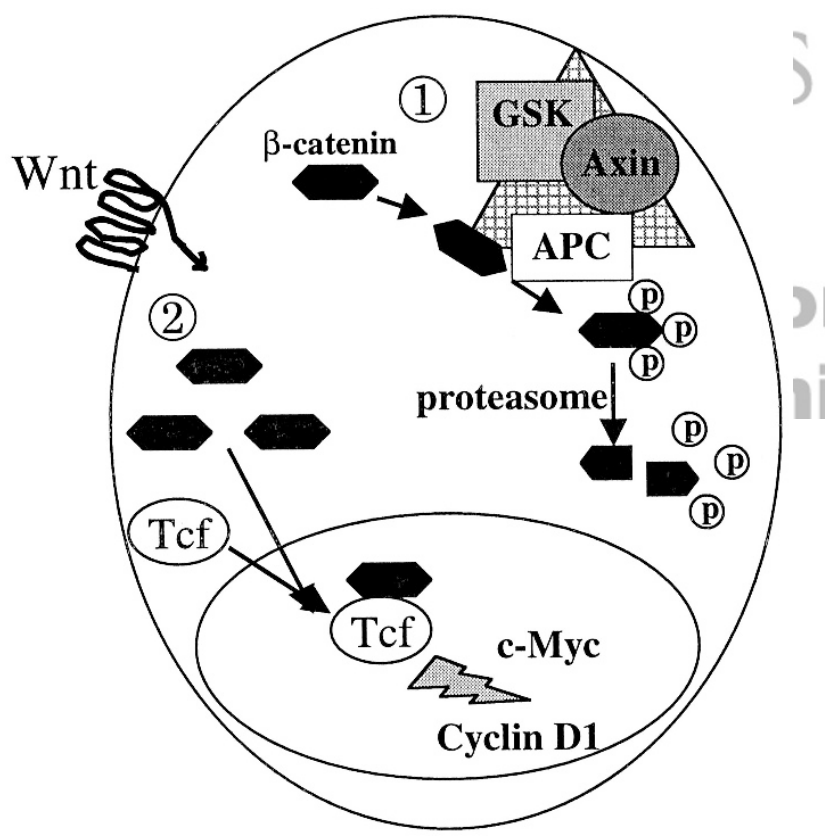

FIGURE 1. Signaling pathway of $\beta$-catenin. A, in the absence of signal or $\beta$-catenin mutations, $\beta$-catenin is targeted by the multiprotein complex of adenomatous polyposis coli, GSK3- $\beta$, and Axin for phosphorylation. Phosphorylated $\beta$-catenin is then degraded by the ubiquitin-proteasome pathway. $\mathbf{B}$, mutations in $\beta$-catenin or Wnt signaling stabilize $\beta$-catenin that can interact with T-cell factor to activate transcription of target genes including $\mathrm{c}-M y c$ and cyclin D1, which stimulates cell proliferation. lated with tumor stage, grade and prognosis (12, 13).

Although altered expression of $\beta$-catenin is believed to be caused by mutations in CTNNB1, limited data in cutaneous melanoma (CM) have thus far not shown a good correlation between mutation status and expression pattern of $\beta$-catenin. Rubinfeld et al. (10) evaluated 26 melanoma cell lines and revealed $\beta$-catenin mutations in only 6 of these samples. In vivo, nuclear accumulation of $\beta$-catenin was found during CM tumor progression, but this aberrant expression was rarely the result of $\beta$-catenin mutations $(14,15)$. These data suggest that mechanisms other than mutations in CTNNB1 may result in stabilization of $\beta$-catenin in CM.

We have studied a large series of CM at the level of DNA, mRNA, and protein. Our data suggest that posttranslational events are responsible for the altered distribution of $\beta$-catenin in the majority of CM.

\section{MATERIALS AND METHODS}

Fifty-six primary CM and 35 metastases from 73 patients were included in this study. From 10 patients, both the primary $\mathrm{CM}$ and the metastasis were available for analysis, and multiple metastases were analyzed in 6 patients. In 70 cases, the material was received freshly; a representative part of the material was snap-frozen in liquid nitrogen-cooled isopentane and stored at $-80^{\circ} \mathrm{C}$ until used for reverse polymerase chain reaction (RT-PCR); the other part was fixed in neutral buffered formalin and embedded in paraffin. For immunohistochemistry, 80 buffered formalin-fixed, paraffin-embedded malignant pigment cell lesions were used. These included 48 primary CM and 32 metastatic melanoma. For RT-PCR, we used 70 frozen tissue samples, consisting of 35 primary $\mathrm{CM}, 27$ metastatic melanoma, and 8 cases of normal skin. Mutation analysis with denaturing gradient gel electrophoresis (DGGE) gels was performed on paraffin-embedded or frozen tissue of 73 tumors (43 primary $\mathrm{CM}$ and 30 metastases) by the DGGE technique and sequencing. As positive controls in mutation analysis, DNA from 18 fresh-frozen and formalin-fixed pilomatrixomas was used because this tumor is known to harbor several CTNNB1 mutations (16)

\section{DNA and RNA Extractions}

For mutation analysis of the 73 cases, genomic DNA was isolated from 10 consecutive frozen whole-tissue sections of $20-\mu \mathrm{m}$ thickness by proteinase $\mathrm{K}$ digestion and phenol-chloroform extraction according to standard procedures.

For RT-PCR, total RNA was extracted from 10 sections of $20-\mu \mathrm{m}$ thickness in all 70 cases using 
Trizol reagent (Life Technologies, Merelbeke, Belgium). Two micrograms of total RNA was converted into cDNA using Superscript Reverse Transcriptase according to the manufacturer's recommendations (Life Technologies). The RT-PCR for the constitutively expressed Forkhead transcription factor gene at chromosome 13 served as a control test for the mRNA quality.

\section{PCR and DGGE and Sequence Analysis}

\section{Polymerase chain reaction}

A 176-bp fragment of CTNNB1 exon 3 was amplified by PCR. Thermal cycling was carried out with the GeneAmp PCR system 9600 (Perkin-Elmer Applied Biosystems, Lennik, Belgium) in final volumes of 50 $\mu \mathrm{L}$, containing $10 \mathrm{~mm}$ of Tris- $\mathrm{HCl}(\mathrm{pH} 8.3), 50 \mathrm{~mm}$ of $\mathrm{KCl}, 2 \mathrm{~mm}$ of $\mathrm{MgCl}_{2}$, $200 \mu \mathrm{M}$ of each dNTP, $0.2 \mu \mathrm{M}$ of each primer (5'-forward -GCTGATTTGATGGAGTTGGACAT-3'; 5'-reverse-[GC]-GACTTGGGAGGTATCC ACATCC- 3'), 500 ng of DNA, and $2.5 \mathrm{U}$ of Taq polymerase AmpliTaq Gold, Perkin Elmer, Lennik, Belgium). A 40-bp GC-clamp was attached to the reverse primer $([\mathrm{GC}]=$ CGCCCGCCGCGCCCCGCGCCCGGCCCGCCGCCCCCGCCCG) and proved to be sufficient for the demonstration on DGGE of the control samples. The amplification protocol consisted of 40 cycles with denaturation at $94^{\circ} \mathrm{C}$, annealing at $60^{\circ} \mathrm{C}$, and extension at $72^{\circ} \mathrm{C}$ for 1 minute. An initial denaturation step of $94^{\circ} \mathrm{C}$ for 10 minutes and a final incubation at $72^{\circ} \mathrm{C}$ for 2 minutes were included.

\section{Denaturing gradient gel electrō̄horèsis}

To test the DGGE conditions determined by this approach, DNA from 18 fresh frozen and formalinfixed pilomatrixomas was analyzed. A $12 \%$ polyacrylamide gel containing a $20-50 \%$ gradient of urea and formamide was sufficient to detect mutations in these samples. DGGE was performed as described elsewhere (17). DNA sequencing was done to confirm and identify the mutations.

\section{Real-time RT-PCR analysis}

This procedure is based on the time-point during cycling when amplification of the PCR product is first detected, rather than by the amount of PCR product accumulated after a fixed number of cycles. The parameter Ct (threshold cycle) is defined as the fractional cycle number at which the fluorescence generated by cleavage of the probe passes a fixed threshold above baseline (18). The $\beta$-catenin target gene copy number in unknown samples is quantified by measuring $\mathrm{Ct}$ and by using a standard curve to determine the starting copy number.

A standard curve was constructed for $\beta$-catenin and for the glyceraldehyde-3-phosphate dehydrogenase gene, as an endogenous control. Serial dilutions (in triplicate) of total RNA from normal skin were made in DEPC water with 1000, 500, 200, 100, 50,20 , and $10 \mathrm{ng}$ of normal skin. The series of diluted human total RNAs were aliquoted and stored at $-80^{\circ} \mathrm{C}$ until use. The target amount of the unknown samples was divided by the endogenous reference amount to obtain a normalized target value. Final results, expressed as $N$-fold differences in $\beta$-catenin gene expression relative to the glyceraldehyde-3-phosphate dehydrogenase gene and the calibrator, were calculated as described elsewhere (19)

All PCR reactions were performed in an ABI Prism 7700 Sequence Detection System (Perkin-Elmer Applied Biosystems). The reaction mixture contained the TaqMan universal Master Mix (Perkin-Elmer Applied Biosystems, Part 4304447), $1 \mu \mathrm{L}$ of the cDNA, 15 pmol of each primer (described above), and 10 pmol of FAM (6-carboxy-fluorescein)labeled beta-catenin TaqMan probe (5'-FAMCCATGGAACCAGACAGAAAAGCGGC-3'; Eurogentec, Seraing, Belgium). The thermal cycling conditions comprised an initial denaturation step at $94^{\circ} \mathrm{C}$ for 10 minutes and 40 cycles at $94^{\circ} \mathrm{C}$ for 20 seconds and at $60^{\circ} \mathrm{C}$ for 1 minute.

Experiments were performed in triplicate for each data point. Each PCR run included the seven points of the standard curve (a set of three serially diluted normal human skin cDNAs), a no-template control, and the unknown cDNAs.

\section{Immunohistochemistry}

Cellular localization of $\beta$-catenin was determined by immunohistochemistry, using the anti- $\beta$ catenin (E-5) mouse monoclonal antibody (Santa Cruz Biotechnology, Boechout, Belgium). Incubation with the anti- $\beta$-catenin antibody $(1: 40)$ for 30 minutes at room temperature was followed by peroxidase-conjugated EnVision + reagent (DAKO, Glostrup, Denmark) for another 30 minutes. Enzyme activity was developed using 3-amino-9ethylcarbazole and $\mathrm{H}_{2} \mathrm{O}_{2}$, revealing a bright-red color that contrasted well with the brown melanin pigment. Controls in which the primary antibody was replaced by phosphate buffered saline did not reveal specific staining. Normal epidermis served as internal positive control.

The membranous, cytoplasmic, and nuclear immunoreactivity was semiquantitatively scored as 0 (no staining), $1+(<25 \%$ immunoreactive cells in a scattered distribution), $2+$ (between $25 \%$ and $50 \%$ stained cells, arranged in sheets or nests), $3+$ (between $50 \%$ and $75 \%$ of immunoreactive cells), and $4+$ (immunoreactivity in virtually all pigment cells). In primary $\mathrm{CM}$, the immunoreactivity was assessed both in the whole tumor as well as in the distinctive growth phases in other words, the RGP and the VGP. 


\section{Statistical Analysis}

For statistical evaluation, the nonparametric Mann-Whitney test or Spearman correlation test was used, when appropriate. Quantitative data were expressed as mean \pm SEM. Significance was accepted when $P<.05$. Statistical analysis was performed using Statview 5.0.1 (SAS Institute, Cary, NC) on a Power Macintosh computer.

Because immunohistochemistry, RT-PCR data, and mutation analysis could not be performed on all cases, the number of used cases varied between the statistical evaluations (Table 1). Therefore, the number of cases is mentioned with each statistical evaluation.

\section{RESULTS}

\section{Immunohistochemistry and RT-PCR}

Immunohistochemistry for $\beta$-catenin was performed on 48 primary $\mathrm{CM}$ and 32 metastases (Fig. 2). The results are summarized in Tables 2 and 3 . Thirty-seven $(77 \%)$ primary tumors and $7(32 \%)$ metastases expressed membranous $\beta$-catenin. Almost half of the primary CM showed additional weak cytoplasmic staining. In four cases, a gradual loss of membranous $\beta$-catenin staining occurred when CM progressed from the RGP to the VGP. Nuclear staining was seen in only 11 out of 48 primary $\mathrm{CM}$ and in 6 out of 32 metastases. In 9 patients, both their primary $\mathrm{CM}$ and subsequent metastasis could be evaluated. In 8 of these cases, membranous $\beta$-catenin staining was seen in the primary CM but disappeared in the metastasis.

There was no correlation between the relative number of cells with membranous expression of $\beta$-catenin and the number of cells with nuclear or cytoplasmic expression of $\beta$-catenin ( $r=0.161, P=$ .1127 and $r=0.006, P=.4714$, respectively, 80 cases). The number of cells with membranous expression of $\beta$-catenin was significantly higher in primary CM than in metastases $(P<.0001,48$ primary MM and 32 metastases; Table 2). In the 35 primary CMs with an RGP and a VGP, the RGP contained a significantly higher number of cells with membranous $\beta$-catenin expression as com- pared with the case of the VGP $(P=.0031$; Table 3$)$, and the number of cells expressing membranous $\beta$-catenin in the VGP was significantly higher than in metastatic melanoma $(P=.0018)$. No significant differences between groups were observed for nuclear and cytoplasmic expression of $\beta$-catenin $(P \geq$ 0.1053).

$\beta$-Catenin expression was semiquantitatively determined with RT-PCR on frozen tissue from 35 primary $\mathrm{CM}$ and 27 metastases. The amounts of RNA tended to be larger in metastatic melanoma than in primary $\mathrm{CM}(P=.0714,35$ primary $\mathrm{CM}$ and 27 metastases; Fig. 3).

There was a significant inverse correlation between the amount of RNA and the proportion of cells with membranous expression of $\beta$-catenin ( $r$ $=-0.369, P=.0015$, 55 cases); no correlation existed between the amount of RNA and the number of cells with nuclear or cytoplasmic expression of $\beta$-catenin $(r=0.3, P=.4187$ and $r=0.2, P=.2535$, respectively, 55 cases).

\section{Mutational Analysis of CTNNB1}

Mutational analysis of CTNNB1 exon 3 was successfully carried out on DNA extracted from 43 primary $\mathrm{CM}$ and 30 metastases (Fig. 2). Heavy pigmentation or insufficient tumor material prevented this analysis in the other 19 cases. PCR and DGGE and nucleotide sequencing revealed $\beta$-catenin mutations in 2 primary $\mathrm{CM}$ and in 1 metastatic melanoma. At/codon 37, a TCT to CCT change (S37P) and a TCT to TAT change (S37Y) were detected in a lymph node metastases and a lentiginous $\mathrm{CM}$, respectively. The lymph node metastases showed intense cytoplasmic and membranous $\beta$-catenin staining, whereas the lentiginous $\mathrm{CM}$ showed a loss of membranous $\beta$-catenin staining from the RGP to the VGP. An additional GAC to GAA change at codon 32 (B32Q) was observed in the lentiginous $\mathrm{CM}$. The third case, a superficial, spreading $\mathrm{CM}$, revealed a GAC to GGC change in codon 32 (D32G). This case also presented a weak nuclear staining pattern and a loss of membranous staining toward the VGP.

\section{TABLE 1. Analysis of $\boldsymbol{\beta}$-Catenin in Primary Cutaneous Melanoma and Metastases}

\begin{tabular}{|c|c|c|c|c|c|}
\hline Group & Histology & $N$ & Mutation Analysis & RT-PCR & Immunohistochemistry \\
\hline Primary & Clark I & 3 & 3 & 1 & 1 \\
\hline \multirow[t]{5}{*}{$\mathrm{CM}$} & Clark II & 4 & 2 & 3 & 4 \\
\hline & Clark III & 20 & 13 & 15 & 16 \\
\hline & Clark IV & 19 & 16 & 10 & 17 \\
\hline & Clark V & 10 & 7 & 6 & 10 \\
\hline & Total & 56 & 43 & 35 & 48 \\
\hline \multirow[t]{3}{*}{ Metastases } & Skin metastasis & 8 & 6 & 8 & 8 \\
\hline & Lymph node metastasis & 27 & 24 & 19 & 24 \\
\hline & Total & 35 & 30 & 27 & 32 \\
\hline
\end{tabular}

RT-PCR, reverse transcriptase polymerase chain reaction. 

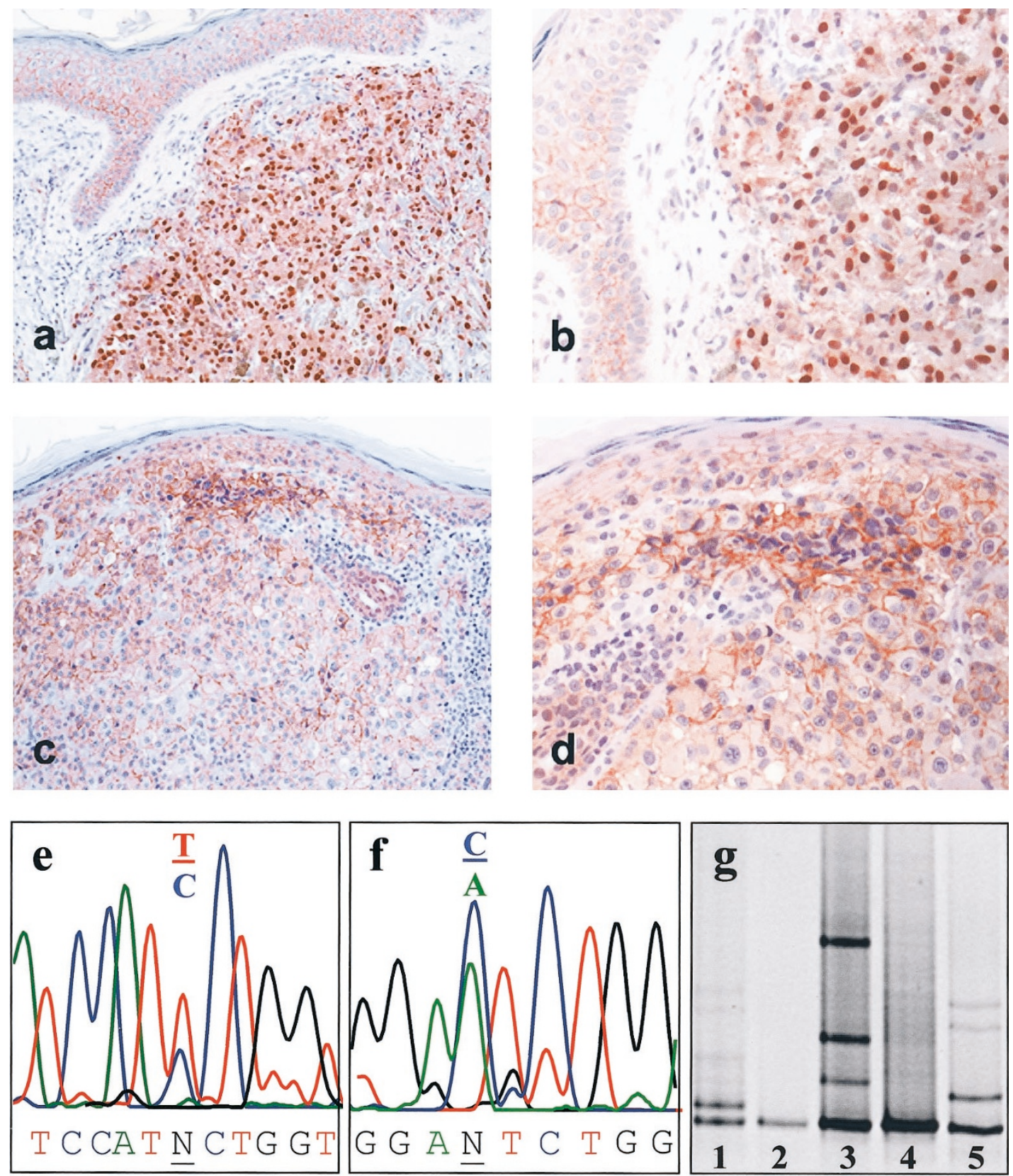

FIGURE 2. The membranous, cytoplasmic, and nuclear immunoreactivity was scored semiquantitatively as 0 (no staining), $1+(<25 \%$ immunoreactive cells in a scattered distribution), $2+$ (between $25 \%$ and $50 \%$ stained cells, arranged in sheets or nests), $3+$ (between $50 \%$ and $75 \%$ of immunoreactive cells), and $4+$ (immunoreactivity in virtually all pigment cells). A, in transit metastasis of a primary cutaneous melanoma (CM) with cytoplasmic and nuclear staining for $\beta$-catenin. B, higher magnification of Figure 1A; normal epidermis shows membranous staining without nuclear or cytoplasmic staining. C, gradual loss of membranous $\beta$-catenin staining toward vertical growth phase in primary CM. D, higher magnification of Figure 1C. Panels $\mathbf{E}$ through $\mathbf{G}$ are of chromatograms and denaturing gradient gel electrophoresis (DGGE) gel demonstrating $\beta$-catenin mutations. E, a primary tumor: lentiginous CM IV; there is a TCT to CCT change at codon 37. F, a metastasis; there is a GAC to GAA change at codon 32 . G, a DGGE gel with the following, by lane: in lane 1, a TCT to TTT mutation in a pilomatrixoma; in lane 2, a wild-type sample; in lane 3, a GAC to GAA mutation in a lentiginous CM; in lane 4, a wild-type sample; and in lane 5, the metastasis showing a TCT to CCT mutation.

\section{DISCUSSION}

$\beta$-Catenin is a dual-function protein that acts not only as a structural component of adherens junctions but also as an effector molecule involved in the Wnt pathway. Upon mitotic signaling by the wnt pathway, GSK-3 $\beta$ is antagonized, and $\beta$-catenin is no longer phosphorylated but stabilized; its cytosolic levels increase, and binding to transcription factors, in other words, lymphoid enhancer factor and T-cell factor, can occur $(9,20)$. Upon migration to the nucleus, transactivation of target genes such as myc and cyclin D1 may result in cell proliferation. Constitutive stabilization of $\beta$-catenin and consequent persistent gene transactivation are believed to represent a common feature in tumorigenesis and may be caused by mutations or deletions in $\beta$-catenin, APC, and GSK3 $\beta$. 
TABLE 2. Membranous, Cytoplasmic, and Nuclear Expression of $\beta$-Catenin in 48 Primary $\mathrm{CM}$ and 32 Metastases

\begin{tabular}{|c|c|c|c|c|c|c|}
\hline \multirow[t]{2}{*}{ Staining Pattern } & \multicolumn{5}{|c|}{$\begin{array}{l}\text { Proportion of Cells Positive for } \\
\quad \beta \text {-Catenin, } n(\%)\end{array}$} & \multirow{2}{*}{$\begin{array}{c}P \\
\text { Value }^{\mathrm{a}}\end{array}$} \\
\hline & 0 & $1+$ & $2+$ & $3+$ & $4+$ & \\
\hline \multicolumn{7}{|l|}{ Membranous } \\
\hline Primary CM & $5(11)$ & $12(25)$ & $15(31)$ & $13(27)$ & $3(6)$ & $<0.0001$ \\
\hline Metastasis & $25(78)$ & $3(10)$ & $2(6)$ & $1(3)$ & $1(3)$ & \\
\hline \multicolumn{7}{|l|}{ Cytoplasmic } \\
\hline Primary CM & $20(42)$ & $11(23)$ & $13(27)$ & $4(8)$ & $0(0)$ & 0.2136 \\
\hline Metastasis & $11(34)$ & $6(19)$ & $8(25)$ & $5(16)$ & $2(6)$ & \\
\hline \multicolumn{7}{|l|}{ Nuclear } \\
\hline Primary CM & $37(77)$ & $10(21)$ & $1(2)$ & $0(0)$ & $0(0)$ & 0.8741 \\
\hline Metastasis & $26(81)$ & $2(6)$ & $1(3)$ & $0(0)$ & $3(10)$ & \\
\hline
\end{tabular}

TABLE 3. Membranous, Cytoplasmic, and Nuclear Expression of $\beta$-Catenin in the RGP and VGP of 35 Primary CM

\begin{tabular}{|c|c|c|c|c|c|c|}
\hline \multirow[t]{2}{*}{ Staining Pattern } & \multicolumn{5}{|c|}{$\begin{array}{l}\text { Proportion of Cells Positive for } \beta \text {-Catenin, } \\
\qquad n(\%)\end{array}$} & \multirow{2}{*}{$\begin{array}{c}P \\
\text { Value }^{\mathrm{a}}\end{array}$} \\
\hline & 0 & $1+$ & $2+$ & $3+$ & $4+$ & \\
\hline \multicolumn{7}{|l|}{ Membranous } \\
\hline RGP & $2(6)$ & $8(23)$ & $10(28)$ & $12(34)$ & $3(9)$ & 0.0 \\
\hline VGP & $14(40)$ & $6(17)$ & $8(23)$ & $5(14)$ & $2(6)$ & \\
\hline \multicolumn{7}{|l|}{ Cytoplasmic } \\
\hline RGP & $16(46)$ & $7(20)$ & $10(28)$ & $2(6)$ & $0(0)$ & 0.83 \\
\hline VGP & $16(46)$ & $9(25)$ & $8(23)$ & $2(6)$ & $0(0)$ & \\
\hline \multicolumn{7}{|l|}{ Nuclear } \\
\hline RGP & $25(71)$ & $8(23)$ & $2(6)$ & $0(0)$ & $0(0)$ & 0.9238 \\
\hline VGP & $24(69)$ & $11(31)$ & $0(0)$ & $0(0)$ & $0(0)$ & \\
\hline
\end{tabular}

a Mann-Whitney test.
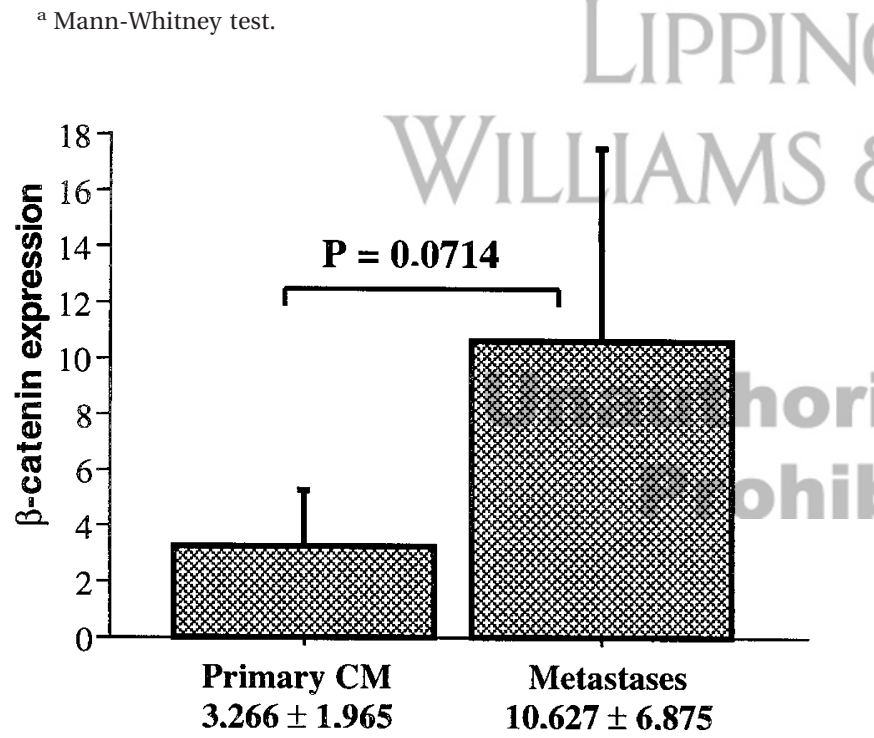

FIGURE 3. Real-time detection of $\beta$-catenin expression levels in primary and metastatic melanoma. Statistical analysis was performed by using the Mann-Whitney test. Bars, mean \pm SD.

In several cancers, these mutations are accompanied by loss of membranous expression and nuclear localization of $\beta$-catenin. A correlation between loss of membranous $\beta$-catenin expression and tumor grade or metastatic potential has been demonstrated in esophageal, gastric, and colorectal carcinoma $(21,22)$. In CM cell lines, activating mutations in the phosphorylation sites of $\beta$-catenin result in stabilization of this protein (10). Our study as well as that of others $(14,15)$ shows, however, that this is a rare event in CM. These discrepancies between CM cell lines and primary or metastatic melanoma raise the possibility that $\beta$-catenin mutations in CM cell lines may not have been present in the primary from which these cell lines are derived but in contrast have arisen during in vitro culture. Another possibility is that $\mathrm{CM}$ with $\beta$-catenin mutations is more readily adapted to in vitro culture than is $\mathrm{CM}$ lacking $\beta$-catenin mutations. Yet a third possibility is that $\beta$-catenin mutations are present as a subclonal genetic defect in some CM and that the neoplastic cells with $\beta$-catenin mutations have growth advantages in vitro in comparison to cells lacking $\beta$-catenin mutations. Consistent with the latter hypothesis is the finding that $\beta$-catenin mutations in prostate cancer occur only in selected regions of primary tumors (23).

In our study, CTNNB1 mutations (S37Y, S37P, D32E, and D32G) were found in two primary CM and in one metastatic melanoma, and these point mutations were similar to those previously reported by Huang et al. (24). The mutations in codon 37 involve the sequence for GSK- $3 \beta$ phosphorylation, implicated in the down-regulation of $\beta$-catenin through phosphorylation of serine residues. Mutations at these sites thus suggest stabilization and accumulation of $\beta$-catenin. The metastasis harboring this mutation showed a strong cytoplasmic accumulation of $\beta$-catenin, whereas the primary $\mathrm{CM}$ affected with this codon 37 mutation did not show any nuclear or cytoplasmic staining of $\beta$-catenin.

Apart from mutations at codon 37, we found two cases with mutations at a neighboring site, in particular at codon 32, flanking the serine at codon 33. Others have already reported mutations at codon 32 (25). Residues at codons 32, 33, and 34 (DSG) are consensus motifs of the $\beta$-catenin and inhibitor of nuclear factor $\kappa \mathrm{B}$ protein families, which are supposed to be necessary for ubiquitin-dependent proteolysis (8). Mutations at codon 32, as presented here, may thus change the protein structure and thereby inhibit the phosphorylation of $\beta$-catenin or its recognition by the ubiquitin-dependent proteolysis system. The two primary CM affected by this mutation showed only a loss of membranous staining for $\beta$-catenin.

Whereas mutations in CTNNB1 may result in nuclear accumulation of the protein, our study and those of others show that CM with cytoplasmic and/or nuclear staining do not always show mutations in codons 32 or 37 (14); therefore, other $\beta$-catenin-activating mechanisms are likely to exist. It is unlikely that mutations in other exons of 
CTNNB1 are responsible for an aberrant expression of $\beta$-catenin because exon 3 harbors the most important residues for GSK3- $\beta$ phosphorylation and for ubiquitin-dependent proteolysis. Mutations in APC resulting in a truncated form or complete loss have been described in two CM cell lines (10), but its relevance for the in vivo situation is still unclear. In a recent study, no loss of heterozygosity $(\mathrm{LOH})$ in the APC gene could be detected in a small series of CM (26). Inactivation of the APC modifier phospholipase A2-activating protein (PLAP) may also contribute to stabilization of $\beta$-catenin; the PLAP gene is localized at $9 \mathrm{p} 21$, a chromosomal region that is frequently affected by $\mathrm{LOH}$ in $\mathrm{CM}$ (27). Another explanation of membranous $\beta$-catenin release may be the down-regulation of the cadherins. Herlyn et al. (28) described indeed loss of E-cadherin in melanoma cells, which rendered them resistant to control by keratinocytes. In addition, loss of E-cadherin was associated with gain of $\mathrm{N}$-cadherin in CM (2830). Such a shift in cadherin profiles may render melanocytic cells adhesive to nonepithelial cells such as endothelium and fibroblasts, or it may favor uncontrolled proliferation, migration, and invasion without the need of membranous $\beta$-catenin.

Our study enabled us to analyze the expression of $\beta$-catenin during tumor progression; in nine patients, both the primary $\mathrm{CM}$ and the metastasis could be studied. A significant loss of membranous $\beta$-catenin staining was found in metastatic as compared with primary CM. These results are analogous to those reported by Sanders et al. (31) that showed a maintained membranous/ $\beta$-catenin staining in dysplastic nevi and primary CM but a significant loss in the metastatic growth phase. In addition, we evaluated the different growth phases of the primary $\mathrm{CM}$ in all patients and noted a significant loss of membranous $\beta$-catenin staining when lesions progressed from RGP to VGP. Our results therefore show that loss of membranous $\beta$-catenin staining is an important event in both early and late stages of tumor progression of CM. This loss of membranous staining was, as in previous studies, not correlated with nuclear accumulation of $\beta$-catenin or with mutations in CTNNB1.

To our knowledge, this is the first study that combines RT-PCR for $\beta$-catenin expression with immunohistochemistry. RT-PCR revealed a significant inverse correlation between the amount of RNA and the proportion of cells with membranous expression of $\beta$-catenin. The amount of RNA tended to be higher in metastatic melanoma than in primary $\mathrm{CM}$, but the majority of metastases had lost membranous expression of $\beta$-catenin. On the other hand, no correlation was found between RNA levels and cytoplasmic/nuclear expression. These data also suggest that during tumor progression, posttranslational events occur that interfere with membrane insertion of the protein.

In conclusion, our combined approach has shown that loss of membranous expression of $\beta$-catenin in CM correlates with tumor progression and may be indicative of a loss of adhesional function of the E-cadherin system. This loss of expression is only rarely accompanied by activating mutations in exon 3 of CTNNB1. Therefore, further studies should be aimed at searching for posttranslational events resulting in malformation of $\beta$-catenin and accumulation of the protein in the cytoplasm and/or nucleus.

Acknowledgments: The authors thank Louis Libbrecht for help with the statistical analysis of the results, Bernadette Smets for excellent immunohistochemical work, and Miet Vanherck and Vera Vanhentenrijk for assistance in the molecular pathology lab.

\section{REFERENCES}

1. Silye R, Karayiannakis AJ, Syrigos KN, Poole S, Van Noorden $\mathrm{S}$, Batchelor W, et al. E-cadherin/catenin complex in benign and malignant melanocytic lesions. J Pathol 1998;186:350-5.

2. Tang A, Eller MS, Hara M, Yaar M, Hirohashi S, Gilchrest BA. E-cadherin is the major mediator of human melanocyte adhesion to keratinocytes in vitro. J Cell Sci 1994;107:983-92.

3. Gumbiner BM, McCrea PD. Catenins as mediators of the cytoplasmic functions of cadherins. J Cell Sci 1993;17:155-8.

4. Behrens J, von Kries JP, Kuhl M, et al. Functional interaction of beta-catenin with the transcription factor LEF-1. Nature 1996;382:638-42.

5. Munemitsu S, Albert I, Souza B, Rubinfeld B, Polakis P. Regulation of intracellular $\beta$-catenin levels by the adenomatous polyposis coli (APC) tumor suppressor protein. Proc Natl Acad Sci U S A 1995;92:3046-50.

6. Rubinfeld B, Albert I, Porfiri E, Fiol C, Munemitsu S, Polakis P. Binding of GSK $3 \beta$ to the APC- $\beta$-catenin complex and regulation of complex assembly. Science 1996;272:1023-6.

7. Behrens J, Jerchow BA, Wurtele M, Grimm J, Asbrand C, Wirtz R, et al. Functional interaction of an axin homolog, conductin, with $\beta$-catenin, APC, and GSK3 $\beta$. Science 1998; 280:596-9.

8. Aberle H, Bauer A, Stappert J, Kispert A, Kemler R. $\beta$-catenin is a target for the ubiquitin-proteasome pathway. EMBO J 1997;16:3797-804.

9. Korinek V, Barker N, Morin PJ, et al. Constitutive transcriptional activation by a beta-catenin-Tcf complex in APC-/colon carcinoma. Science 1997;275:1784-7.

10. Rubinfeld B, Robbins P, El-Gamil M, et al. Stabilization of beta-catenin by genetic defects in melanoma cell lines. Science 1997;275:1790-2.

11. Takayama T, Shiozaki H, Shibamoto S, et al. Beta-catenin expression in human cancers. Am J Pathol 1996;148:39-46.

12. Shimazui T, Schalken JA, Giroldi LA, et al. Prognostic value of cadherin-associated molecules (alpha-, beta-, and gammacatenins and p120cas) in bladder tumors. Cancer Res 1996; 56:4154-8.

13. Richmond PJ, Karayiannakis AJ, Nagafuchi A, et al. Aberrant E-cadherin and alpha-catenin expression in prostate cancer: correlation with patient survival. Cancer Res 1997;57:318993 
14. Rim DL, Caca K, Hu G, Harrison FB, Fearon ER. Frequent nuclear/cytoplasmic localization of $\beta$-catenin without exon 3 mutations in malignant melanoma. Am J Pathol 1999;154: 325-9.

15. Omholt K, Platz A, Ringborg U, Hansson J. Cytoplasmic and nuclear accumulation of $\beta$-catenin is rarely caused by CTNNB1 exon 3 mutations in cutaneous malignant melanoma. Int J Cancer 2001;92:839-42.

16. Chan EF, Gat U, McNiff JM, Fuchs E. A common human skin tumour is caused by activating mutations in $\beta$-catenin. Nat Genet 1999;21:410-3.

17. Demunter A, Ahmadian MR, Libbrecht L, Stas M, Baens M, Scheffzek $\mathrm{K}$, et al. A novel $N$-RAS mutation in malignant melanoma is associated with excellent prognosis. Cancer Res 2001;61:4916-22.

18. Heid CA, Stevens J, Livak KJ, Williams PM. Real time quantitative PCR. Genome Res 1996;6:986-94.

19. Bieche I, Onody P, Laurendeau I, Olivi M, Vivaud D, Lidereau $\mathrm{R}$, et al. Real-time reverse transcription-PCR assay for future management of ERBB2-based clinical applications. Clin Chem 1999;45:1148-56.

20. Morin PJ, Sparks AB, Korinek V, Barker N, Clevers H, Vogelstein $\mathrm{B}$, et al. Activation of $\beta$-catenin-Tcf signalling in colon cancer by mutations in $\beta$-catenin or APC. Science 1997;275:1787-90.

21. Nakanishi Y, Ochiai A, Akimoto S, Kato H, Watanabe $H$, Tachimori $\mathrm{Y}$, et al. Expression of E-cadherin, $\alpha$-catenin, $\beta$-catenin and plakoglobin in esophageal carcinomas and its prognostic significance. Lab Invest 1997;54:158-5.

22. Woo DK, Kim HS, Lee HS, Kang YH, Yang HK, Kim WH. Altered expression and mutation of $\beta$-catenin gene in gastric carcinomas and cell lines. Int J Cancer (Pred Oncol) 2001; 95:108-13.
23. Voeller HJ, Truica CL, Gelmann EP. Beta-catenin mutations in human prostate cancer. Cancer Res 1998;58:2520-3.

24. Huang H, Fujii H, Sankila A, Mahler-Araujo BM, Matsuda M, Cathomas G, et al. $\beta$-catenin mutations are frequent in human hepatocellular carcinomas associated with hepatitis $C$ virus infection. Am J Pathol 1999;155:1795-801.

25. Miyoshi Y, Iwao K, Nagasawa Y, Aihara T, Sasaki Y, Imaoka S, et al. Activation of the beta-catenin gene in primary hepatocellular carcinomas by somatic alterations involving exon 3. Cancer Res 1998;58:2524-7.

26. Ichihashi N, Kitajima Y. Loss of heterozygosity of adenomatous polyposis coli gene in cutaneous tumors as determined by using polymerase chain reaction and paraffin section preparations. J Dermatol Sci 2000;22(2):102-6.

27. Ruiz A, Nadal M, Puig S, Estivill X. Cloning of the human phospholipase A2 activating protein (hPLAP) gene on the chromosome 9p21 melanoma deleted region. Gene 1999;18: 239:155-61.

28. Herlyn M, Berking C, Li G, Satyamoorthy K. Lessons from melanocyte development for understanding the biological events in neavus and melanoma formation. Melanoma Res 2000;10(4):303-12.

29. Hsu MY, Wheelock MJ, Johnson KR, Herlyn M. Shifts in cadherin profiles between human normal melanocytes and melanomas. J Invest Dermatol Symp Proc 1996;1(2):188-94.

30. Li G, Satyamoorthy K, Herlyn M. N-cadherin-mediated intercellular interactions promote survival and migration of melanoma cells. Cancer Res 2001;61:3819-25.

31. Sanders DSA, Blessing K, Hassan GAR, Bruton R, Marsden JR, Jankowski J. Alterations in cadherin and catenin expression during the biological progression of melanocytic tumours. J Clin Pathol: Mod Pathol 1999;52:151-7.

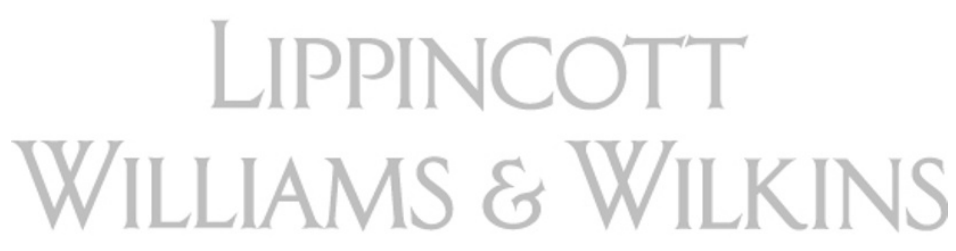

